\title{
"Providing for the Active Participation of the Entire Assembly": Petr Eben's Liturgical Music with Congregational Participation
}

\author{
Manfred Novak
}

\section{Introduction}

Petr Eben was one of the few internationally renowned composers who embraced the implications of the Second Vatican Council (Vat. II) on writing music for the liturgy and who took up the challenge of providing music for the active participation of the entire congregation. ${ }^{192}$ This active participation (participatio actuosa) is a keyword of Vat. II's liturgical reform. The term goes back to the Motu proprio Tra le sollecitudini (1903) by pope Pius X, in which he wished for the congregation to join in the liturgical chants. ${ }^{193}$ This original meaning of participatio actuosa, the singing congregation, never since ceased being one of the term's core concepts, even if its meaning was expanded in the course of the $20^{\text {th }}$ century. ${ }^{194}$ Contrary to many of his colleagues, Petr Eben found

192 "Composers, filled with the Christian spirit, should feel that their vocation is to cultivate sacred music and increase its store of treasures. Let them produce compositions which have the qualities proper to genuine sacred music, not confining themselves to works which can be sung only by large choirs, but providing also for the needs of small choirs and for the active participation of the entire assembly of the faithful." Constitution on the Sacred Liturgy Sacrosanctum Concilium (1963), art. 121.

193 "In particolare si procuri di restituire il canto gregoriano nell'uso del popolo, affinché i fedeli prendano di nuovo parte più attiva all'officiatura ecclesiastica, come anticamente solevasi." Pius X, Tra le sollecitudini, art. 3, La Santa Sede, accessed November 4, 2015, http://w2.vatican.va/content/ pius-x/it/motu_proprio/documents/hf_p-x_motu-proprio_19031122_sollecitudini.html.

194 For a detailed discussion of the term, concept, and history of participatio actuosa see Stephan Schmid-Keiser, Aktive Teilnahme: Kriterium gottesdienstlichen Handelns und Feierns (Bern: Peter Lang, 1985). For a recent and concise summary emphasising the term's relevance to liturgical music see Rudolf Pacik, "Aktive Teilnahme: Schlüsselbegriff der erneuerten Liturgie," in Im Klangraum der Kirche: Aspekte-Positionen-Positionierungen in Kirchenmusik und Liturgie, ed. Martin Hobi (Zürich: Chronos, 2007), 27-52. 
inspiration in taking up the compositional challenges inherent in the requirement of including congregational singing. ${ }^{195}$

Any composer who wants to include congregational participation in his liturgical music is challenged by two main questions:

1. Which compositional means or techniques can I apply in order to enable a group of untrained singers to participate in and perform my composition?

2. How can I keep true to my aesthetic convictions and personal style, when I have to keep things simple enough for the congregation to take part?

These two questions will be considered on the following pages and exemplified by analysis of three works by Petr Eben, Deutsches Ordinarium (1965), ${ }^{196}$ Marien-Vesper (1968), ${ }^{197}$ and Missa cum populo (1981-1982). ${ }^{198}$ These works were chosen because they specify a part for the congregation among a larger ensemble (cantor, schola, choir, organ, brass and percussion instruments) and are accessible in published editions. Of the three, Deutsches Ordinarium is the composition on the smallest scale. This fact makes it especially interesting with regard to the aesthetical question: Do limited musical resources and the inclusion of the congregation necessitate a compromise of style? The answers Petr Eben gives in his music will contribute to the understanding of a part of his compositional output. They may also show a way for composing liturgical music after Vat. II, thanks to Eben

195 "Ich glaube, es ist vollkommen abhängig vom Komponisten, ob er in der erneuerten Liturgie eine Chance sieht oder sie nur als Einschränkung empfindet. Das liegt ganz an ihm, und er hat wirklich die Möglichkeit, nicht nur eine Chance, sondern sogar eine Inspiration darin zu finden. [...] Für mich war z. B. das Problem der Miteinbeziehung des Volksgesanges schon inspirierend. Das ist nicht einfach, aber bestimmt ein Problem, das für den Komponisten sehr interessant ist." (Petr Eben in an interview with Franz Karl Praß1, “'Diese Botschaft war mir immer nahe': Ein Gespräch mit dem Prager Komponisten Petr Eben zu seinem 65. Geburtstag,” Singende Kirche 41, No. 1 (1994): 5-9, here 7.)

196 This work was titled Deutsches Ordinarium when it was published with German text by pro organo (P. O. 3037) in 1994. Originally it set the liturgical texts in Czech language to music.

197 This work was titled Marien-Vesper when it was published with both German and Latin text underlay by pro organo (P. O. 3019) in 2004. Its original language is Catalan because it was commissioned by the Benedictine monastery of Montserrat for the Vespers of the feast of the Birth of the Blessed Virgin Mary.

198 Missa cum populo was commissioned by Radio France, premiered at Avignon festival in 1983, and published by Süddeutscher Musikverlag Heidelberg (SM 2780) in 1986. Eben composed two organ verses complementing Missa cum populo, both of which are written on Gregorian melodies: Pueri Hebraeorum to be played during the offertory and Adoro Te devote during the communio. These two verses (composed in 1982) were premiered in 1986 and are published by Universal Edition (cf. Kateřina Vondrovicová, Petr Eben: Leben und Werk (Mainz: Schott, 2000), 239-240, 256). As they are neither included in the edition of Missa cum populo by Süddeutscher Musikverlag nor include any vocal parts, they are not discussed in this paper. 
being rated one of few composers who met both liturgical and artistic demands in their compositions. ${ }^{199}$

\section{The Technical Question}

\subsection{Deutsches Ordinarium}

This composition is written for one single vocal part plus organ accompaniment, ${ }^{200}$ which always doubles the vocal part in its top line. The pro organo edition suggests an optional distribution of phrases among three different performing forces: cantor, schola (unison choir), and congregation. Thus there is a variety of performing options, including schola plus organ (without congregation) or congregation plus organ (without cantor and/or schola), which allows for an adaptation of the work according to the availability of singers. ${ }^{201}$ This simple design provides optimal support for the members of the congregation, who always get doubled by the organ, can always be doubled by other vocalists (cantor and/or schola), and in case of antiphonal execution will be able to listen to some of their melodies right before they themselves are supposed to sing.

The melodic structure is diatonic with the rare chromatic alteration of single pitches; the Kyrie is built on a Lydian scale, the Gloria on a Dorian scale, the Sanctus on a major scale, the Agnus Dei on minor scale. The Credo is somewhat more complex: Its key signature is $\mathrm{F}$ major but parts of it make extensive use of the pitches A flat and $\mathrm{C}$ flat. Most often the melodies progress stepwise, often thirds are used, and the largest interval is the fifth. Note values are restricted to crotchets and quavers; rare minims or dotted crotchets can be found at the end of phrases or motifs; parts of the Credo are recited on a single note without any specified rhythm. Short melodic phrases are repeated several times, occasionally showing small alteration or development in later repetitions. Again the Credo is a bit different: It is the only movement that employs transposition and sequence. Furthermore, it includes the melody of the well-known Easter chant "Christ ist erstanden" as a quotation.

All the mentioned features aim at keeping the melody simple and relatively easy to perform. Even though the Kyrie includes a melodic tritone, this interval is well embedded in the organ accompaniment (both pitches forming it sound in the organ before they

199 Cf. the judgement of Niko Firnkees: "Insgesamt verstehen es nur wenige Komponisten, Praktikabilität und ästhetisches Niveau unter einen Hut zu bringen. In jüngster Zeit scheint dies dem Tschechen Petr Eben gelungen zu sein.” Niko Firnkees, Sakrale Musik nach 1945 als musikpädagogische Aufgabe (Augsburg: Wißner, 2000), 63.

200 There is also a version for a cappella choir (SATB), published by pro organo (P. O. 3038).

201 In case of a performance with congregation plus organ alone, some phrases of the Kyrie may be skipped. 
have to be sung), and in case of a performance with cantor and schola the congregation members would hear the phrase twice before they are supposed to sing.

Ex. 1: Petr Eben, Deutsches Ordinarium, Kyrie, mm. 1-3 (excerpt from pro organo 3037)

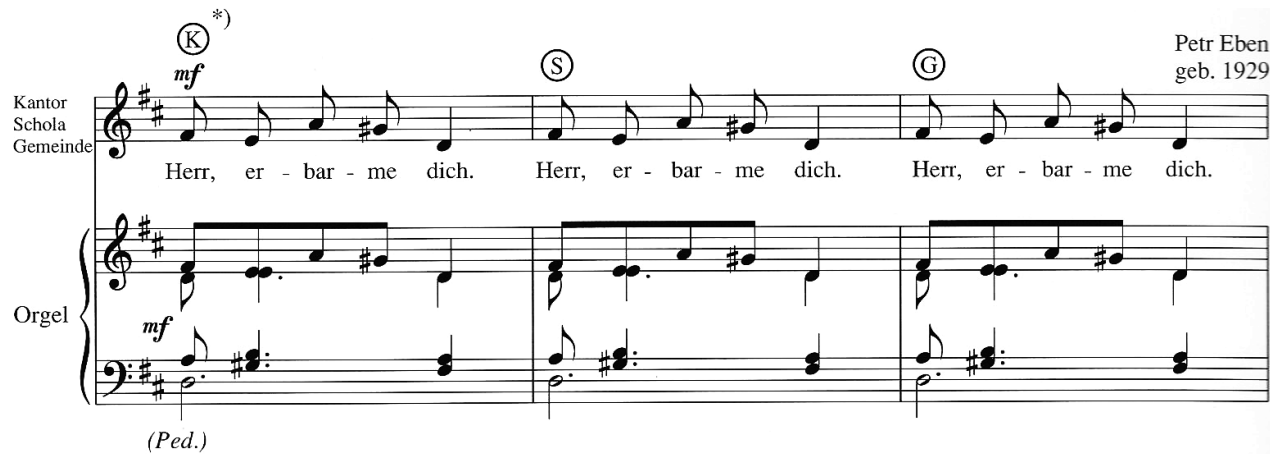

Also the organ accompaniment is kept simple and basically provides chordal harmony for the melody. How this inclination towards practicability avoids being simplistic, and whether or not it affects Eben's style, is discussed in point 2 of this article.

\subsection{Marien-Vesper}

Marien-Vesper was composed in 1968 for a symposium organized by the Benedictine abbey of Montserrat, who invited several renowned composers to discuss issues of liturgical music after Vat. II. In the frame of this symposium two liturgical works in the vernacular (Catalan) for the feast of the Birth of the Blessed Virgin Mary were premiered, a mass proper by Ernst Krenek ${ }^{202}$ and Vespers by Petr Eben. Marien-Vesper consists of five movements (settings of psalms 109, 112, 126; Responsorium breve; Magnificat) written for soprano, baritone, mixed choir, congregation and organ. The congregation is included in the first two psalms, the Magnificat, and (optionally) in the Responsorium breve.

In the first psalm Eben restricted himself to one monophonic voice plus organ. The congregation sings the refrain ("Antiphon") between the psalm verses. The choir performs the first statement of the refrain (and recites the psalm verses, which are set to newly composed formulas and alternately entrusted to the male or female section of the choir). Thus the congregation gets the chance to listen to the D major melody of the refrain before it joins in for the recurrences. The organ accompaniment gives harmonic support for the pitches, but is rhythmically more independent in comparison with Deutsches Ordinarium. The lack of rhythmic support does not, however, cause any problems for

202 Proprium Missae per a la festa de la nativitat de la mare de Deu, op. 202 (for soloists SATB, choir SATB, congregation, clarinet, 2 trumpets, percussion, viola, harp and organ). 
the congregation, thanks to the choir not having its own part at that time and therefore being able to support the people.

In the second psalm the congregation can take part in the psalm itself, while the antiphon is sung by the choir. The congregation takes part with a call, "Hochlobt den Namen des Herrn," which is inserted after each verse and is introduced by the female voices of the choir who state it (in unison), before the congregation and the male voices of the choir repeat it with the support of the organ doubling the melodic line. The unison makes it still more convenient for the congregation to listen to the melody and recognize it as the clue for its entry.

Ex. 2: Petr Eben, Marien-Vesper, $2^{\text {nd }}$ psalm, mm. 62-66 (excerpt from pro organo 3019)

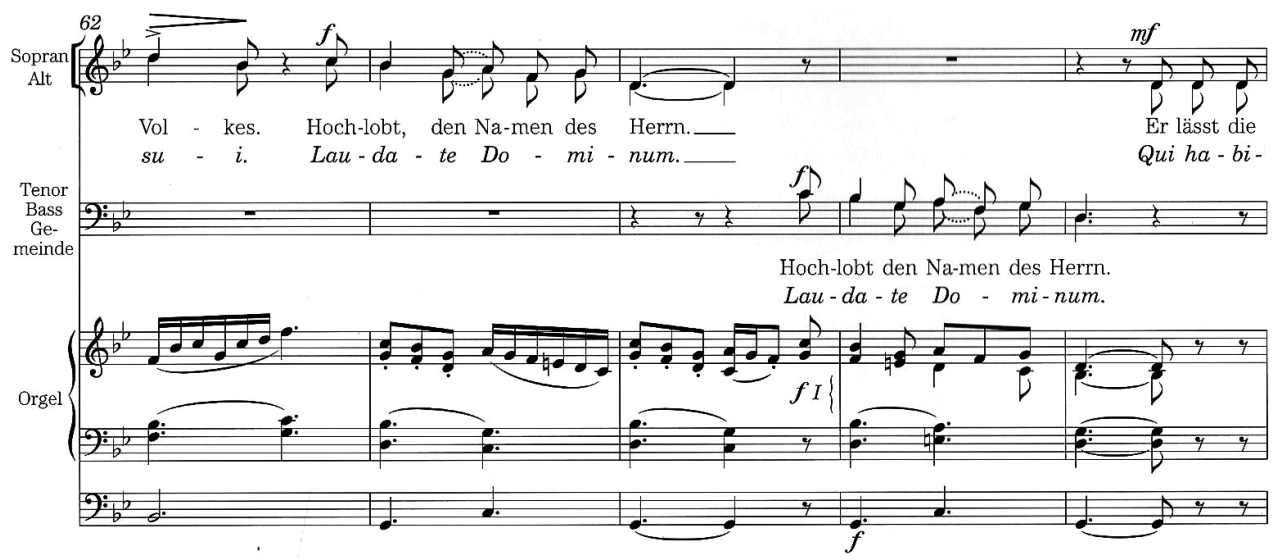

The short, repeated call, which is performed by the congregation and the male voices as a response to the psalm verses of the female voices, adds to the joyous, rhythmic drive of the movement. For a contrasting middle section, the choir sings a quieter, calmer chordal passage, making the whole psalm an A-B-A form framed by the antiphon and preceded by a short organ introduction.

For the fourth movement, the Responsorium breve, Eben provides two versions of the Versiculum to choose from. The second option, Versiculum $b$, includes the congregation with a simple recitation. This recitation is started by the baritone soloist, who delivers his text on g; only the last note goes down to e, concluding the sentence. The congregation repeats the very same model with new text. The recitation formula is embedded in harmonies and contrapuntal lines provided by the choir and the organ. This is the first instance in which congregation and choir have different, overlapping parts.

Just like the first psalm, the Magnificat starts with an organ prelude and a monophonic antiphon in D major. Here the congregation is invited to sing right from the beginning. Again, the choir is free to join singing the antiphon, which is accompanied by the organ in chordal style. The choir proceeds polyphonically with the text of the Magnificat, in which the congregation participates during the last four verses (set to the same melody 
as the antiphon), with the choir adding four part harmony to the melody of the sopranos and the congregation.

\subsection{Missa cum populo}

Petr Eben himself commented on his Missa cum populo in the booklet accompanying a recording published in 1992 with Panton:

My fourth Mass - MISSA CUM POPULO - was commissioned by Radio France for the Avignon Festival, where its premiere was conducted by Georges Durand. There was, however, a difficult condition attached to that composition: it had to meet the wish of the Second Vatican Council that the congregation should be able to take an active part in the performance of the concert piece. I therefore confronted the four-voice mixed church choir, supported by organ, with an una voice part for the congregation, reinforced by four brass instruments. The question of the responses is solved in the Kyrie by making the congregation respond with the same simple theme to the various phrases of the choir; in the Gloria it is resolved by an ostinato, with the congregation repeating the Gregorian chant of the opening words, in the Credo by a choral recitation by the congregation, with a drum supporting the rhythm, in the Sanctus by contrast of a slow descending sub-theme which rings out at double speed in the "Hosannah", and in the Agnus Dei finally in the form of a passacaglia in which the choir builds a climax over the singable theme of the congregation before reverting to a quietly dying-away conclusion. ${ }^{203}$

Eben's comments concentrate on formal aspects; it is well worth looking a bit closer: The "simple theme" of the Kyrie consists of only two different pitches and is supported and harmonized by the brass instruments ( 2 trumpets, 2 trombones). It enters after the "various phrases of the choir" so that the congregation basically alternates with the choir; a very short overlap in the notation prevents the choir from joining the congregation, though. The Kyrie theme first occurs when the congregation is supposed to sing it, so the people have to know it beforehand (or learn it from the brass players during the piece). Its entry pitch is easy to find from the ending notes of the preceding phrases sung by the choir. ${ }^{204}$ The last occurrence of the theme is in augmentation, with the choir joining forces with the brass section and the congregation. Subsequently, a coda follows for which the congregation is divided into three groups, all reciting "Kyrie eleison" on equal quavers

203 Petr Eben (1992; Panton 81 1141-2911), CD booklet, 5 (no pagination). Missa cum populo was recorded live at a concert on October 6, 1987. This CD also includes Vox clamantis and Concerto for Organ and Orchestra No. 2.

204 Petr Eben himself confirms that this was a very conscious, practicable consideration: "Ein Motiv, das als sechs- oder siebentöniger Refrain gebaut ist, ist sicher ganz leicht einzustudieren. Der Komponist muß dabei aber immer ganz realistisch denken, z. B. im Fall des Kyrie dieser Missa cum populo habe ich das so gemacht, daß dieser Refrain immer mit dem Ton beginnt, mit dem der Chor aufhört. Das sind die praktischen Dinge, die man nicht vergessen darf." Cf. Praß1, Singende Kirche 41: 7. 
on the note D but starting at different points of time. This repeated quaver movement is supported by the trombones and the tomtom.

The chant motif that serves as an ostinato is the intonation of the Gloria from the Gregorian Missa Cunctipotens genitor (Missa IV) and thus can be seen as rather familiar to a congregation. The ostinato is supported by the brass and the organ pedal (ad. lib.). The ostinato (and thus the congregation) pauses for the middle-section (figure 3 in the score) and is resumed again for the ending (figure 5 in the score). The entry pitch for the recurrence is clearly given by the choir, and the ostinato is supported by instruments, just as in the beginning.

The recitation in the Credo is a spoken rhythmic motif ("Credo in unum Deum"), thus the effort of finding or learning new pitches is avoided. According to Eben, there was still another reason for choosing recitation as a means of participation of a big crowd: the momentum of confession. ${ }^{205}$ The congregation is not only supported by the drums and, occasionally, by the brass instruments, but the congregation's entries are also announced by a signal of the gong. Matching the text of the Credo sung by the choir, the text of the recited motif is changed to "Credo in Jesum Christum" and "Credo in Spiritum Sanctum" at the appropriate places. For the latter change, the rhythm had to be adapted.

The "slow descending sub-theme" of the Sanctus actually is the beginning of the Gregorian Missa XVIII (in feriis adventus et quadragesimae et ad missam pro defunctis). These three notes on two different pitches are used as an ostinato, which is introduced by the trumpet and subsequently supported by the brass section, the organ pedal, and the choir basses. The ostinato motif is abandoned for the Hosanna and the Benedictus, before it starts the second Hosanna, again introduced by the trumpet, but at double speed.

In the Agnus Dei the congregation's participation is similar to that of the Kyrie: after the choir has sung its phrases ("Agnus Dei, qui tollis peccata mundi") the congregation answers "Agnus Dei, miserere nobis" while the choir still keeps its last note. The congregation has to find its entry pitch (D, a fifth down from the choir note A) from the organ, which provides the D-A sound two crotchets earlier. The "singable theme", which is supported by the brass instruments, contains a chromatically descending line, but its strong, expressive character helps to recognize, remember and (hopefully) sing it.

205 "[...] dort, wo es schwierig ist, wie z. B. beim Credo, habe ich mich auf das Rezitieren der Gemeinde in einem starken Rhythmus konzentriert, nicht nur deshalb, weil es leichter einzustudieren ist, sondern auch, weil es gerade beim Credo für mich wichtig war, das Moment des Bekenntnisses auszudrücken, durch die Massenrezitation wurde dieses eigentlich noch gewichtiger." Cf. Praßl, Singende Kirche 41: 8. 
Ex. 3: Petr Eben, Missa cum populo, Agnus Dei, initial entry of the congregation (excerpt from Süddeutscher Musikverlag Heidelberg 2780)

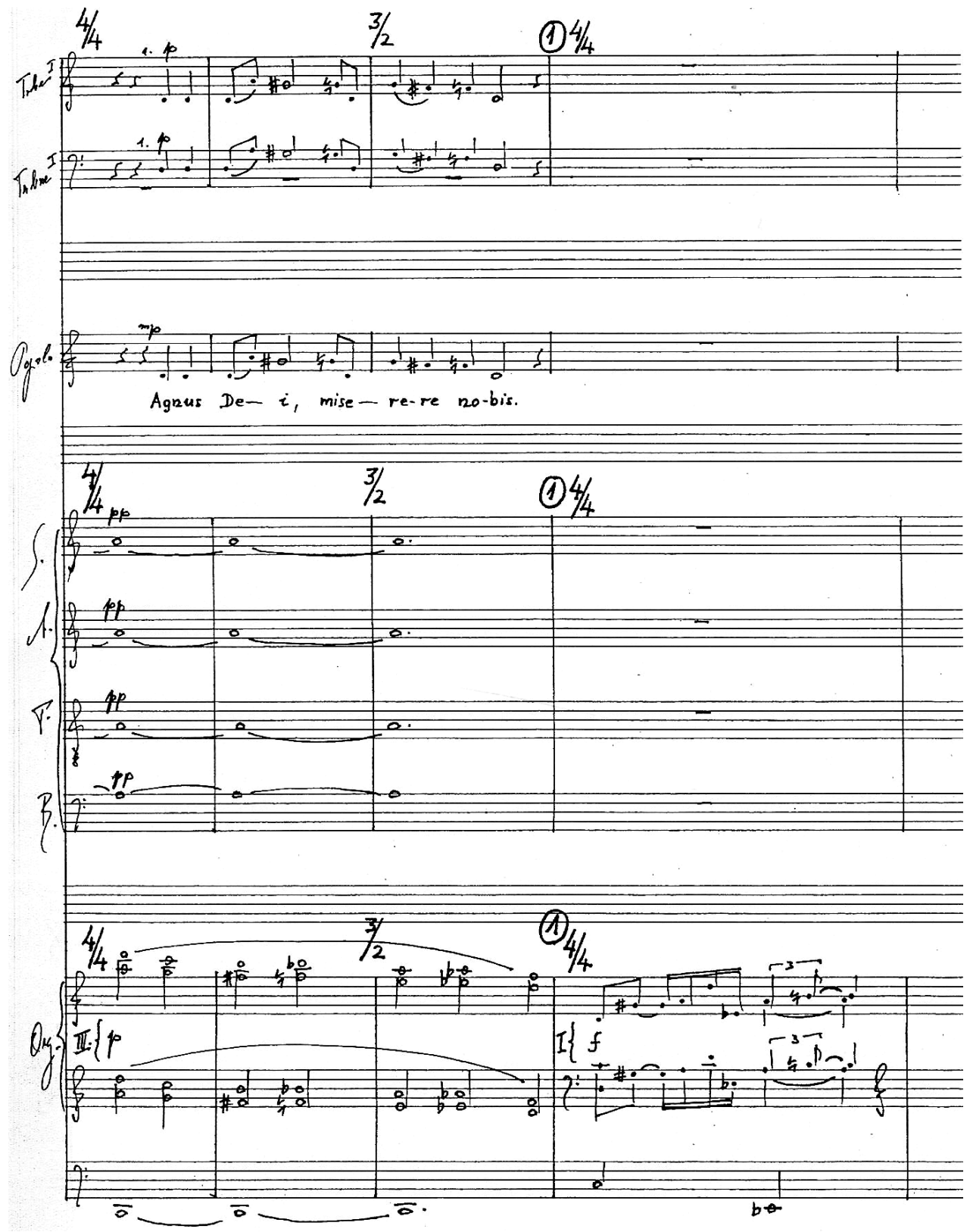

Just as in the Kyrie, there is no chance of hearing and thus learning that line during performance before the congregation is supposed to enter. For the third Agnus (" $[. .$.$] dona$ 
nobis pacem") the line turns into the passacaglia theme that was mentioned by the composer. It is doubled in a variety of combinations by the choir basses, the brass players, and the organ. According to the dynamic arch (a gradual development from $p$ to $f f$ and back to $p p$ ) Eben divides the congregation in male and female singers. He lets the male singers start in $m p$, adds the females for the fourth statement of the theme (at $m f$ ), indicating $f$ at the following statement. The females drop out again in the ninth statement $(\mathrm{mf})$, and the male singers finish with the next statement in $p$. This division of the congregation (which includes the task of finding the correct places to enter and drop out again), the dynamic differentiation, the melodic shape (chromaticism), entering with new melodic material, and an entry pitch different from the preceding choir pitch make the Agnus Dei the most demanding movement for the congregation.

\subsection{Commentary}

The "difficult condition" of composing for congregation is twofold: A congregation consists of untrained singers, and it does not rehearse. Thus, its part should be written in a way so that it is easy to sing and, if it makes use of newly composed material, ideally can be learnt during the course of the performance. In the light of the preceding parts of this article, a few aspects of such easy "singability" will be discussed here. Some of them are interdependent, some may be rather obvious; still it seems interesting to see how Petr Eben dealt with them.

To begin with, the range for the congregation should avoid extremes and be suited for higher as well as lower voice types, because any congregation is a mixed group of singers. The ranges that Eben used are $\mathrm{c}^{1}-\mathrm{d}^{2}$ (Deutsches Ordinarium), $\mathrm{d}^{1}-\mathrm{e}^{2}$ (Marien-Vesper), and $\mathrm{d}^{1}-\mathrm{c}^{2}$ (Missa cum populo), respectively one octave lower for the male singers. Thus, Eben stayed within the standard ranges of congregational songbooks, even if $\mathrm{e}^{2}$, which Eben used for the Magnificat, the climax of the work (and also the liturgical celebration!), is definitely the upper limit. ${ }^{206}$ The features of the melodies and motifs used for congregational participation have already been mentioned (see 1.1); it's worth noting the rhythmic elementariness, which all the three works have in common.

Regarding support for the congregation, Deutsches Ordinarium and Marien-Vesper follow very similar ideas: The organ plays along with the congregation, and the singers of the choir are free to join the congregation on its part (although that option is only specified in the score in exceptional cases), thanks to the fact that overlaps between congregation and the other vocal parts are avoided. Deviations from this rule can be found in the Responsorium breve, where the soloists would be free to join the congregation instead (not specified), and the ending of Magnificat (see 1.2). Such support by vocal doubling is most effective, because it is easiest to sing along with other singers. For Missa cum populo, Eben made a different, more complex choice: Basically the members of the

206 When Petr Eben composed Marien-Vesper in the 1960s, the average ranges in congregational songbooks were slightly higher than they are nowadays. 
congregation are doubled by the brass players and can rely on them as their partners. Additionally, at places they are also supported by the organ or some vocal parts. This multiple support has the advantage of possible variation: Single support groups can switch in and out, they can be freed for other musical tasks of the composition, and no specific group or instrument is bound to always perform with the congregation. The last Kyrie statement may serve as an example: Here Eben switches the usual combinations congregation-brass and choir-organ to congregation-organ and choir-brass. By that time the congregation has sung its motif often enough so that this switch will probably not confuse even untrained singers.

The issue of melodic clues for the congregation's entry pitches has been mentioned in 1.3; with a few exceptions (Kyrie and Agnus Dei from Missa cum populo, the entry in Magnificat from Marien-Vesper) these clues are very clear and hardly to be missed. But the congregation also has to know the time of entering and sometimes, in case of ostinati, the time of dropping out, an issue which got considerably less attention by the composer. For responsorial forms or such execution, which apply to Deutsches Ordinarium and the first psalm of Marien-Vesper, the constant alternation helps to follow the structure of the composition, and the congregation will relatively easily figure out when to enter again. These forms are common for liturgical music and thus well-known. The issue gets more sensitive when the formal design gets more varied and therefore less straightforward. In the second psalm of Marien-Vesper, for example, the congregation participates with the common form of a call, but this call is integrated in a measured composition and recurs at irregular intervals. Before any such recurrence, in addition to the melodic clue provided by the choir singers, Eben writes an always identical, characteristic figure in the organ accompaniment, which serves as rhythmic clue for the entry. The congregation's entry in the Magnificat is even more demanding: Neither do the singers get the specific pitch, nor would the short rest of the organ give much of a rhythmic clue, and even less so that similar writing occurs already earlier in the organ without indicating an entry of the congregation. However, the musical structure following the entry is a broad chorale being performed by the whole ensemble (choir plus organ), which is why the exact entry point of the congregation is less crucial in this place. The issue of rhythmic clues gets more important in Missa cum populo, because the forms of congregational participation are more complex in this work. The Credo shows a neat solution: The spoken response of the congregation, which recurs at irregular intervals, is always introduced by two strokes of the gong, which are clearly heard, set the tempo, and in this way become a part of the response. In the other movements, however, this helpful rhythmic signal is missing, which is hardly a problem in the Gloria, where the ostinato motif is first sung by the officiating priest and repeated by the congregation. In the Sanctus, where the motif is first played by the first trumpet, it is more difficult to catch because a congregation is more used to answer to singers (and, correspondingly, to text). But the entry is well supported by the remaining brass section and the organ pedal, and the rhythmic structure is simple. Still there are some open questions: How does the congregation know when to enter again after having paused during the respective middle sections? It might follow a text sheet 
providing the text sung by the choir. How do the people know when to stop singing their ostinato (only in the Hosanna the ostinato ends with the ending of the movement)? Do we expect them to count their statements? Really problematic in these aspects are the Kyrie and the Agnus Dei: The congregation's motifs or phrases are neither sung nor played ahead of time, and any rhythmic cues are absent. The first occurrences of the "Kyrie" are at least at regular intervals, but in the course of the piece the intervals get irregular. And for the entries of the divided groups of the congregation at the end of the movement there are no cues at all. Similar issues can be observed in the Agnus Dei: The first two occurrences are regular, but there is no clue for starting the ostinato, only at its entry the congregation gets doubled by the bass singers and the first trombone. The trumpets enter together with the congregation's females, and they drop out at the same time as well. But these are "hints" which a singer would notice only in hindsight, the necessary clues before the "events" are missing. And the question of when to end the ostinato again remains still unanswered for the congregation.

Of course, it is generally possible to solve all of these issues by supporting the congregation with a separate unison choir, which can include more experienced singers, which can be rehearsed beforehand, and which the congregation can cling to. ${ }^{207}$ Although there are no such hints in the score of Missa cum populo, Petr Eben was in favour of supporting the congregation with an additional choir, as he wrote in a letter to choir director Nick Strimple. ${ }^{208}$ Another consideration would be that a conductor directs the congregation. Whatever solution one may find, possibly also dependent on the conditions imposed by the room, there are some passages in Missa cum populo for which providing some additional support for the congregation seems advisable, even if there is a chance of rehearsing with them ahead of time. ${ }^{209}$

With regard to formal design, Eben used exclusively common forms of liturgical music for congregational participation in the two earlier compositions: calls, responses/refrains, litany, antiphonal singing, and strophic design at the end of Magnificat. Those short and repetitive forms (with the exception of the last two) are easily learned, remembered

207 The published editions of two liturgical compositions by Ernst Krenek hint at this option. In the concluding movement of Proprium für das Dreifaltigkeitsfest, op. 195 (Bärenreiter 4122), the part for the congregation is labelled "1. Chor (Gemeinde ad lib.)", although this monophonic part was originally composed for congregation (see Manfred Novak, "Zeitgenössische Musik für zeitgenössische Liturgie: Liturgische Werke Ernst Kreneks nach dem II. Vatikanischen Konzil mit Gemeindebeteiligung," Singende Kirche 58, No. 3 (2011): 127-133, here 129). In Deutsche Messe, op. 204 (Bärenreiter 5417) it reads "Gemeinde (Chor)."

208 This letter dates from June 4, 1989, and is reproduced in Christopher D. Haygood, "Surmounting Oppression in the Choral Music of Petr Eben: An Analysis of the Missa Adventus et Quadragesimae" (PhD diss., University of Southern California, 2013), 102. Speaking of several performances of Missa cum populo, Eben wrote: "[...] and I was always very happy with the involvement of the congregation (the better, if supported by a second choir).”

209 Vondrovicová considers rehearsing with the congregation inevitable, cf. Vondrovicová, Eben: Leben und Werk, 240: "Das Werk setzt ein vorheriges Einüben mit dem Kirchenvolk voraus." 
and sung, are widely used for liturgical chants (also for small-scale and short pieces of liturgical music) and are therefore familiar to congregations. In Missa cum populo Eben used similar forms, but partly in a more complex way, and he added ostinato forms (such as the mentioned passacaglia in the Agnus Dei), which are well suited for congregational participation because of their repetitive structure, especially when the ostinato motifs or phrases are relatively short. On the other hand, ostinato forms are less familiar, so it is advisable to carefully introduce them and support the congregation. The congregation's recitation in the Credo is something between a response/refrain and an ostinato, and the Agnus-motif starts as a litany and turns into an ostinato. Such combination and expansion of formal concepts adds variety, makes the music less predictable and thus more interesting, and allows a composer to creatively design the form of his composition. But the less predictable and common the forms for the singing congregation get, the better the support and the clues (entry pitches, entry time, ending of ostinato passages...) for the congregation have to be planned.

\section{The Aesthetical Question}

Liturgical music is functional music. It has to fulfil certain criteria in order to fit in and support the dramaturgy of the rite. How to keep true to one's aesthetic convictions and one's style while writing functional music, specifically liturgical music including congregational participation, is a highly personal question. Petr Eben's aesthetic convictions and some features of his personal style are very supportive of composing liturgical music.

\subsection{Aesthetic Convictions}

Petr Eben sees music and the composer in a role of serving society. This direction towards other people, as opposed to writing music for oneself or for the art's sake, ${ }^{210}$ allows him to respond to outer needs, which may include liturgical functions such as "strengthening bonds of community" and "promoting participation". ${ }^{211}$ Eben's view on music as a message which the composer wants to communicate to his listeners corresponds to another task that liturgical music is required to fulfil, the "proclamation of the Word" ${ }^{212}$ In order to get his message across, Eben looks for common ground between composer

210 Still Petr Eben developed a highly individual, personal musical language. "For Eben, there is no conflict between the imperatives of individual artistic expression (itself pervaded by religious belief) and the necessity of comprehensibility to listeners." Johannes Landgren, Music-Moment-Message: Interpretive, Improvisational, and Ideological Aspects of Petr Eben's Organ Works (Göteborg: Göteborg University, 1997), 74.

211 The functions for liturgical music are quoted from Anthony Ruff, Sacred Music and Liturgical Reform: Treasures and Transformations (Chicago/Mundelein, IL: Hillenbrand, 2007), 17-18.

212 See note 211. 
and listener, ${ }^{213}$ without giving in to mainstream taste. He acknowledges the task of the contemporary composer to create something new, something unfamiliar, yet thinks that the composer should not lose sight of his audience but try to make his musical language understandable. ${ }^{214}$ Even if Eben did not develop these views primarily with regard to liturgical music but while living under a suppressive communist regime where musical utterances had the chance to escape the eyes of the censors, his convictions are supportive of composing liturgical music. At the most basic level, his understanding of music as serving the society and conveying a message makes all the music he writes "functional music" to some degree - or rather, giving the term a positive connotation, "serving music." 215

\subsection{Personal Style ${ }^{216}$}

Eben's views on the role of the composer and of music in society led to the development of certain stylistic features which also lend themselves to writing liturgical music. Those features include adhering to a tonal/modal harmonic language, preferring strong melodic

213 In a broad historical perspective, Eben considers the emancipation of the composer from the church as a social institution (and also a commissioning and employing institution) as one of the main reasons for the gap between nowadays composers and their (potential) audience, because the composer got isolated from society and thus works too subjectively and individualistically for his listeners to follow. Consequently, in writing music for the church he sees a chance to overcome this gap, because the liturgy provides contact between the composer and the (singing) assembly. Cf. James L. Evans, "The Choral Music of Petr Eben" (MA thesis, University College Cork, 1995), 57-58, 118-119.

Cf. Praß1, Singende Kirche 41: 6.

215 For this reason Eben enjoyed writing (educational) music for children, a task with which he could satisfy the Communist authorities and at the same time did not have to compromise his deviating political convictions (cf. Evans, "Choral Music of Petr Eben," 130-131). It was also an opportunity for him to fall back on musical basics such as melody, harmony, tonality or rhythm, something which he considered important for any composer to do from time to time (cf. Praßl, Singende Kirche 41: 6).

216 Studies of Petr Eben's style or a comparison of his liturgical music with his music not written for liturgical usage but at approximately the same time and for approximately the same scoring, which could shed light on the question whether or not he had to alter his style when composing for the liturgy, are impeded by the limited accessibility of printed editions (or manuscripts). There are, however, a number of studies that describe Eben's style by means of analysis of accessible music, and even sketch a development of style during his career. This article relies on these studies when comparing Deutsches Ordinarium, Marien-Vesper and Missa cum populo with the description of Eben's style gained from the analyses of works without congregational participation. Studies taken into account in this process include: Hyungmin Cho, "Constancy and Changes in Peter Eben's Sacred Choral Works: An Overview" (PhD diss., University of Illinois at Urbana-Champaign, 2007); Stefan Daubner, Orchesterwerke Petr Ebens - Struktur und Zeichen (Frankfurt/Main: Peter Lang, 2003); Evans, "Choral Music of Petr Eben"; Haygood, "Surmounting Oppression”; Landgren, Music-Moment-Message; Nelly Matova, "Petr Eben's Oratorio Apologia Sokratus (1967) and Ballet Curses and Blessings (1983): An Interpretative Analysis of the Symbolism behind the Text Settings and Musical Style" (PhD diss., University of Illinois at Urbana-Champaign, 2010). 
themes and motifs and elaborating on them, as well as using quotations, ${ }^{217}$ particularly of Gregorian chant (as melodies conveying the meaning of their texts even if the words are not sung). By quoting a well-known hymn in a composition, the congregation can be included singing this hymn, either with original lyrics or with a newly underlaid text. Eben makes use of this procedure in Deutsches Ordinarium, when he quotes the melody of "Christ ist erstanden" and has parts of the Credo text sung to it. Quotations of Gregorian melodies are chosen in Sanctus and Gloria of Missa cum populo. There he used those quotations as an ostinato, another very characteristic feature of his style which lends itself to congregational participation because of its inherent repetitiveness: The members of the congregation have the chance to learn the short motif on the way, join in at later statements, and take part in the composition for some considerable duration (as long as the ostinato is in effect). Another feature Eben considers important in order to enable an audience to understand his music is a very clear formal design (often using classical forms, especially in his earlier works), which can be observed in all the three works discussed here. Some of the features aiming at congregational participation (refrains, responses, ostinato, antiphonal singing) at the same time help build a clearly perceived musical form. Making use of ostinato even gives rise to musical forms such as the passacaglia, which Eben employed in Agnus Dei ${ }^{218}$ of Missa cum populo as well as in a number of non-liturgical works of both earlier and later origin. ${ }^{219}$ Again we find a fortunate correlation between Eben's personal style and favourable techniques of congregational participation.

The following table lists some features that are discussed in scholarly literature ${ }^{220}$ as being characteristic to Eben's style and their prominent occurrences in the three liturgical works being discussed in this paper. Eben's preference of tonal/modal musical language with clear, often classical, formal design is so pervasive that it is not separately listed.

\begin{tabular}{|l|l|l|l|}
\hline \multicolumn{1}{|c|}{ Stylistic features/techniques } & \multicolumn{1}{|c|}{$\begin{array}{c}\text { Deutsches } \\
\text { Ordinarium }\end{array}$} & Marien-Vesper & \multicolumn{1}{|c|}{$\begin{array}{c}\text { Missa cum } \\
\text { populo }\end{array}$} \\
\hline Homorythmic harmonization & Gl, Cr & $\begin{array}{l}\text { Ps 2, 3; Resp, } \\
\text { Magn }\end{array}$ & $\begin{array}{l}\text { Ky, Gl, Cr, Ag, } \\
\text { Postludium (= Post) }\end{array}$ \\
\hline Pedal-notes & Ky, Gl, Cr & Ps 1, 2, 3, Magn & $\begin{array}{l}\text { Praeludium } \\
\text { (= Prae), Ky, Cr, Ag }\end{array}$ \\
$\begin{array}{l}\text { Parallel chords } \\
\text { Quartal harmony } \\
\text { Bitonality/polytonality }\end{array}$ & Gl, Cr & Ps 3 & $\begin{array}{l}\text { Prae, Cr, Ag, Post } \\
\text { Pr, Ag, Post }\end{array}$ \\
\hline
\end{tabular}

217 Eben's usage of quotations is by no means limited to sacred music: Cf. Desire of Ancient Things, where he quotes Rameau's La Villageoise and Chopin's Prelude op. 28/15 in D flat major.

218 The initial response of the congregation turns into the passacaglia theme later in the movement.

219 E.g. Symphonia gregoriana (1953/54), see Daubner, Orchesterwerke Petr Ebens, 75; Hiob (1987), see Landgren, Music-Moment-Message, 27; Prager Te Deum (1989), see Cho, “Constancy and Changes,” 65.

220 See note 216 . 


\begin{tabular}{|c|c|c|c|}
\hline Classical/functional cadences ${ }^{221}$ & Gl, Cr, Sa, Ag & $\begin{array}{l}\text { Ps 1, 2, 3; Resp, } \\
\text { Magn }\end{array}$ & $\mathrm{Ag}$ \\
\hline Tertian relationships ${ }^{222}$ & $\mathrm{Gl}, \mathrm{Cr}$ & $\begin{array}{l}\text { Ps 1, 3; Resp; } \\
\text { Magn }\end{array}$ & $\begin{array}{l}\mathrm{Ky}, \mathrm{Gl}, \mathrm{Cr}, \mathrm{Sa}-\mathrm{Be} \text {, } \\
\mathrm{Ag}, \text { Post }\end{array}$ \\
\hline (Chromatic) alteration of notes & Gl, Cr, Sa & $\begin{array}{l}\text { Ps 2, 3; Resp, } \\
\text { Magn }\end{array}$ & $\begin{array}{l}\mathrm{Ky}, \mathrm{Gl}, \mathrm{Cr}, \mathrm{Sa}-\mathrm{Be}, \\
\mathrm{Ag} \text {, Post }\end{array}$ \\
\hline Simultaneous major/minor third & & Ps 1,2 & $\mathrm{Sa}-\mathrm{Be}$ \\
\hline Melodic triton & $\mathrm{Ky}$ & Ps 1; Magn & $\begin{array}{l}\text { Ky, Gl, Cr, Sa-Be, } \\
\text { Ag, Post }\end{array}$ \\
\hline Melodic fourths (starting a phrase) & $\mathrm{Gl}, \mathrm{Cr}$ & Ps 1, 3; Magn & $\begin{array}{l}\text { Prae, Ky, Sa-Be, } \\
\text { Ag, } \text { Post }^{223}\end{array}$ \\
\hline Melodic fifths (starting a phrase) & $\mathrm{Sa}$ & Ps 1,2 ; Resp & $\mathrm{Ky}, \mathrm{Ag}$ \\
\hline Successive widening of intervals & $\mathrm{Sa}$ & & Ky \\
\hline Melodies with large ambitus & & Ps 2 & $\mathrm{Ky}, \mathrm{Cr}, \mathrm{Sa}-\mathrm{Be}, \mathrm{Ag}$ \\
\hline Small-scale, chromatic melodies & & & $\mathrm{Ky}, \mathrm{Ag}$ \\
\hline Polytonal triadic melody & & & $\mathrm{Cr}, \mathrm{Ag}$ \\
\hline Change of metre (for declamation) & $\mathrm{Cr}$ & Ps 3 & Prae, Ky, Gl \\
\hline Lombardic rhythms & & & Prae, Gl, Cr \\
\hline Simultaneous use of different tempi & & & Prae \\
\hline Bi- rhythmic texture & & Resp & Prae, $\mathrm{Cr}, \mathrm{Sa}-\mathrm{Be}, \mathrm{Ag}$ \\
\hline Text painting & $\mathrm{Gl}, \mathrm{Cr}$ & Ps 2,3 & $\mathrm{Cr}$ \\
\hline Quotation & $\mathrm{Cr}$ & & Prae, Gl, Sa-Be, Post \\
\hline Use of Gregorian chant & & & Prae, Gl, Sa-Be, Post \\
\hline Old techniques & $\begin{array}{l}\text { Cr (fauxbour- } \\
\text { don) }\end{array}$ & $\begin{array}{l}\text { Ps 2, 3; Magn } \\
\text { (canon) }\end{array}$ & $\begin{array}{l}\text { Prae, Ky, Gl, Cr, } \\
\text { Post (antiphonal); } \\
\text { Prae, Sa-Be, Ag, } \\
\text { Post (canon) }\end{array}$ \\
\hline Juxtaposition of triads & & Magn & Ky, Sa-Be, Post \\
\hline Ostinato & $(\mathrm{Ky}, \mathrm{Gl})^{224}$ & $\begin{array}{l}\text { Ps 2, Resp, } \\
\text { Magn }\end{array}$ & Gl, Cr, Sa-Be, Ag \\
\hline Use of speaking voice & & & $\mathrm{Cr}$ \\
\hline
\end{tabular}

For this category, cadential progressions of V-I and IV-I have been taken into account.

222 Tertian harmony may occur as chord progression as well as harmonic relation between larger form parts.

223 In Postludium the fourth is introduced by the quoted melody.

224 Both movements include short motifs that get repeated. Partly the repetitions are differently harmonized and slightly modified to better fit the changing text. Because of this modification and the short duration of the passages (3-4 statements of each motif) one cannot classify them as ostinati in a strict sense of the word. 


\subsection{Commentary}

The table shows that the amount of characteristic stylistic features in Eben's liturgical compositions is increasing chronologically. This mirrors the increase in numbers of professional performers in the three compositions, whose involvement allows the composer to apply more complex techniques, but also the development of Eben's style to which some features got added in the course of time. According to Stefan Daubner, polytonal triadic melodies only become common in the 1990s, ${ }^{225}$ and Hyungmin Cho classifies the extensive use of the speaking voice as a late feature of Eben's choir music, occurring only as late as the 1990 s. ${ }^{226}$ In this respect, Missa cum populo can even be regarded as stylistically innovative, and the two earlier works are typical examples for their time of origin in not showing any of the features Eben only took up later in his career. Likewise, writing melodies with a large ambitus is something Eben only started in the late 1960s, ${ }^{227}$ and this is precisely reflected in the three liturgical compositions. The melodic tritone and bi-rhythmic structures which started to gain importance in the $1960 \mathrm{~s}^{228}$ are other features reflecting the development of Eben's general compositional style.

There are more typical features that put those three liturgical compositions firmly into the realm of Eben's general musical language: Folk music, which had influenced Eben's style since the 1960s, inspired him to use lombardic rythms, variation of major and minor thirds (which is reflected in their simultaneous use as well as in chromatic alteration, some of which concerns the third), fourths or fifths starting a melody, ${ }^{229}$ and finally, pedal-notes and ostinati. ${ }^{230}$ Features still prominently used in later works include ostinati (in Verba Sapientiae, 1991-1993), ${ }^{231}$ classical cadences (in Prager Te Deum, 1989; Verba Sapientiae), ${ }^{232}$ tonality/polytonality, plainchant (in Prager Te Deum, De tempore, 1991), and old/archaic techniques (such as fauxbourdon in Cantico delle Creature, 1987). ${ }^{233}$ With

225 Cf. Daubner, Orchesterwerke Petr Ebens, 30.

226 Cf. Cho, "Constancy and Changes," 142, 165. Nevertheless, it may be noted that for a short passage Eben did include a solo speaking voice already in his symphonic movement Vox clamantis (1969), a piece in which he employed a number of avant-garde techniques.

227 Cf. Daubner, Orchesterwerke Petr Ebens, 28. In Eben's instrumental music the ambitus can be as wide as two octaves. When writing for the human voice, the ambitus is more limited, but the general tendency of using larger intervals and a larger ambitus remains. In his choir music, Eben occasionally wrote "continuous melodies" which are distributed to several voice parts and thus could cover a larger ambitus than any single voice part. However, this feature is used extensively only in his later works (cf. Cho, "Constancy and Changes," 35), and it does not occur in the three liturgical works being discussed here.

228 Cf. Daubner, Orchesterwerke Petr Ebens, 28.

229 Cf. Daubner, Orchesterwerke Petr Ebens, 28.

${ }^{230}$ Cf. Matova, "Petr Eben's Oratorio," 55.

231 Cf. Cho, "Constancy and Changes," 112, 125, 146.

232 Cf. Cho, "Constancy and Changes," 106, 120, 150.

233 Cf. Cho, "Constancy and Changes," 57. 
regard to the latter, antiphonal writing is especially interesting because it is rooted in practices of ancient liturgical singing. Therefore its usage links to the tradition of liturgical music (as well as to Renaissance polychoral music) and is a successful way of integrating the singing congregation. At the same time it is a technique which again is characteristic of Eben's language and which he also uses in non-liturgical music (for example in Prager Te Deum, and De tempore). ${ }^{234}$ In case of performing Deutsches Ordinarium with choir and/or cantor, the whole cycle could be added to the category "old techniques (antiphonal)". Eben also shows a way of avoiding the inherent danger of music becoming too repetitive and therefore boring, when a short response is used to include the congregation in an antiphonal structure: In Kyrie of Missa cum populo the congregation's short motif at times occurs transposed, differently harmonized (as does the antiphon of the first psalm of Marien-Vesper), in augmentation, or supported by various instrumental sections.

Generally speaking, Deutsches Ordinarium, Marien-Vesper, and Missa cum populo all clearly show Peter Eben's musical language, even if he himself talks of stylistic considerations in composing for the congregation when commenting on Marien-Vesper: "The text set to music there is in the mellifluous Catalan language, to enable members of the congregation to join in the singing at several places. Therefore also this work was styled in an accessible musical idiom, with the organ put in charge of the harmonically sharper passages." ${ }^{235}$ By the hint "with the organ put in charge of the harmonically sharper passages," he provides the key to writing stylistically advanced music even when the congregation is included: More demanding passages are entrusted to trained performers; the more trained performers are available, the less elementary the music needs to be written. This can clearly be seen by comparing Missa cum populo to Deutsches Ordinarium, where more demanding stylistic features such as polytonality, bi-rhythmic structures, and juxtaposition of triads are missing, and thus the harmonic and melodic language is milder. Yet, Eben manages to employ clearly noticeable hallmarks of his style such as tertian progressions, melodic tritons, chromatic alterations of notes (often affecting the third), and parallel chords even so. For very few passages Eben abandons most or all of those characteristics, retreating to a tonal/modal style with mainly functional triadic or seventh chord harmonization and without notes foreign to the scale. ${ }^{236}$

Through his aesthetic convictions, his positive view on the liturgical reform, ${ }^{237}$ his communicative musical language, and his personal interest in composing for the singing congregation, Petr Eben successfully combined artistic demands with functional and practical needs of liturgical music. His impressive achievements in writing for the liturgy

234 Cf. Cho, "Constancy and Changes," 65, 145-146.

${ }^{235}$ Quoted after the booklet accompanying the CD Petr Eben: Religious Works (1992; Supraphon 11 1438-2231), 2 (no pagination).

236 These passages include Agnus Dei and a short section in Credo of Deutsches Ordinarium as well as the first antiphon of the first psalm (recurring antiphons are harmonized differently) and the antiphon of Magnificat of Marien-Vesper.

${ }^{237}$ Cf. Praß1, Singende Kirche 41: 7. 
after Vat. II can still serve as outstanding models for contemporary composers embarking on this road.

\title{
"Providing for the Active Participation of the Entire Assembly": Petr Eben's Liturgical Music with Congregational Participation
}

\begin{abstract}
Petr Eben was one of the few internationally renowned composers embracing the implications of the Second Vatican Council on writing music for the liturgy designed for the active participation of the entire congregation. He took up this challenge and succeeded in meeting both liturgical and artistic requirements. This paper discusses technical and aesthetic questions involved in composing for congregations and exemplifies these questions in analysing three works by Petr Eben: Deutsches Ordinarium (1965), Marien-Vesper (1968) and Missa cum populo (1981-1982).
\end{abstract}

\section{„Určeno pro aktivní spoluúčast celého shromáždění“: liturgická hudba skladatele Petra Ebena s účastí kongregace}

\begin{abstract}
Abstrakt
Petr Eben byl jedním z mála mezinárodně uznávaných skladatelů, kteří ve svém díle reflektovali požadavky Druhého vatikánského koncilu na kompozici liturgické hudby určené pro aktivní spoluúčast celé kongregace. Eben přijal zmíněné požadavky a úspěšně spojil liturgické a umělecké nároky. Studie rozebírá technické a estetické otázky související s kompozicí hudby pro kongregaci; problematika je ilustrována na prríkladu Ebenových děl: Deutsches Ordinarium (1965), Marien-Vesper (1968), and Missa cum populo (1981-1982).
\end{abstract}

\section{Keywords}

$20^{\text {th }}$ century music; church music; congregational participation / participatio actuosa; Petr Eben; liturgical music; sacred music; Second Vatican Council; Deutsches Ordinarium; Marien-Vesper; Missa cum populo.

\section{Klíčová slova}

Hudba 20. století; chrámová hudba; spoluúčast kongregace / participatio actuosa; Petr Eben; liturgická hudba; duchovní hudba; Druhý vatikánský koncil; Deutsches Ordinarium; Marien-Vesper; Missa cum populo. 